\title{
The Effect of Implementing the Experiential Learning Model in Listening Comprehension for the Eleventh Graders at SMAN 1 Telaga Biru
}

Ismail Tahir*

Graduate Program in English Language Teaching, Universitas Negeri Malang, Indonesia

Correspond Author: Ismail Tahir, E-mail: ismailtahir43@yahoo.com

\section{ARTICLE INFO}

Article history

Received: June 16, 2017

Accepted: September 13, 2017

Published: October 31, 2017

Volume: 8 Issue: 5

Advance access: October 2017

Conflicts of interest: Non

Funding: None

\author{
Key words: \\ Experiential Learning, \\ Listening Comprehension, \\ EFL Learners, \\ EFL Classroom, \\ Pre-experimental Study, \\ Language Experience
}

\begin{abstract}
This study is aimed to investigate the effectiveness of the experiential learning in listening comprehension with the focus on the implementation of the class story using language experience at SMAN 1 Telaga Biru. As the pre-experimental research, this study involved one class consisted of 27 students in the eleventh graders. However, most of the students of the eleventh graders in this school have some problems in their listening comprehension. This current research, therefore, aims at finding the result of the students' listening comprehension by using experiential learning in focusing on the class story using language experience for the eleventh graders at SMAN 1 Telaga Biru and defining the students' achievement in listening comprehension by using experiential learning focusing on the class story using language experience. This study also explored the learners' listening comprehension by analyzing the result of the students' pretest and post-test. It was found that the mean of the pre-test was 60 while the mean of the post-test was 80,6 . By analyzing this result, it indicated that the post-test was higher than the pre-test. In conclusion, the finding of this research showed that teaching listening in the eleventh graders of SMAN 1 Telaga Biru using experiential learning in focusing on the class story using language experience was effective to teach students' listening comprehension. Therefore, it can be suggested that it was an alternative way to use of experiential learning focusing on the class story using language experience in teaching listening.
\end{abstract}

\section{INTRODUCTION}

\section{Background of the Study}

As EFL (English as a Foreign Language) learners, students may have daily opportunities for listening and speaking in English as they interact with their teachers and friends/classmates in the school or with their family members at their home and community members in their environment because if the learners want to learn to speak, they should learn first how to understand the spoken language they listen to (Ahmadi, 2016). In relation to listening, it is sometime nonface-to-face such as watching movies, broadcasting media, listening to the loudspeaker audio or listening to the phone. On the other hand, it is also occurred in face-to-face by interspersing with speaking such as having a discussion with teachers, students or other people or having social conversations with them and having some kinds of conversations with many people in various service providers. Therefore, listening can be explained as an active ability (Rost, 2009. cited in Ahmadi, 2016).

In getting the purpose of listening, the learners, especially EFL learners, of course, have a purpose and a communication task. In this situation, they need to be able to understand what the speakers are saying in order be comprehended in listening. They also need to be able to understand the question(s) if the speakers ask them so that they can be able to respond appropriately to face-to-face communication. Related to the listening purposes, the learners have to be careful in listening to every word/sentence they listen. It is aimed to avoid the miscommunications between the listeners and speakers when having a talk. Moreover, in non-face-to-face communication, the listeners/learners need to understand what the speaker(s) say without communicating directly with the speaker(s). Therefore, it is very important for the learners to listen carefully because EFL listening seems as a problematic language skill in the context of foreign language (Nowrouzi, Tam, Zareian, \& Nimehchisalem, 2015. cited in Ulum, 2015).

By considering the problems above, it is necessarily considered by the EFL teachers of how to teach listening for EFL learners in order to gain the students' achievement in listening. It is because if they cannot create an appropriate environment in the listening classroom, teaching English skill then could be a difficult task particularly for EFL teachers (Albadawi, K.H, 2016). Moreover, EFL teachers are expected to implement the appropriate way in enhancing the 
students' ability in listening, especially listening comprehension. Listening comprehension is dealt with the learners' ability to allocate a meaning and understand it (Azmi, B., Celik, B., Yidliz, N., \& Tugrul, M., 2014).

In relation to teaching listening, most of the EFL learners still have some difficulties in listening comprehension (Kurita, 2012), especially in SMAN 1 Telaga Biru. It is found that most of them did not meet the standard score of the listening final test. As a sequence, they had to have a make-up class and a test again. In finding this problem, the researchers had an interview with an English teacher and the students and then did an observation in teaching and learning process. By doing these activities, therefore, the researcher is proposed to conduct a research in seeking the result of the implementation of experiential learning focusing on the class story using language experience. The research conducted by the researcher was a pre-experimental research. Thus the researcher just applied the teaching strategy in one class.

Experiential learning is considered to be implemented in order to solve the students' problem in listening comprehension. The researcher provided this approach focusing on applying the class story language experience during the listening classroom activities. By implementing the class story language experience guided by the experiential learning steps, the teacher makes the students experience by themselves how to listen whether listening to the audio, teacher, or classmates/friends in the classroom. The steps in experiential learning can be drawn in the picture below Figure 1 .

As the new concept in learning through experience, this experiential learning could be brought into the classroom activities. The theory of experiential learning actually involves those four steps above connected to each other (doing, observing, thinking, and planning). The main characteristic of this theory is aimed at exploring the active learning (Sharlanova, 2004). Sharlanova (2004) argued that experiential learning provides the class situation for independent learning, learning by doing, work-based learning, and problem-based learning. It gives a lot the opportunity for both students and teacher in teaching and learning process. The teacher is expected to provide as well as plan an active teaching scenario in order encourage the students' interest to be active in the learning process. By implementing an experiential learning, it is proposed to help students realize themselves in doing or learning something, help teachers become

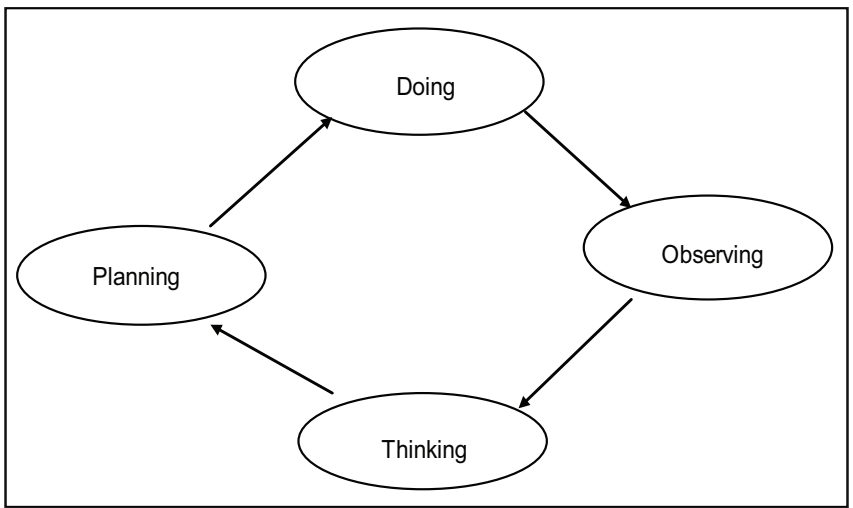

Figure 1. Experiential learning model (Kolb, 2015) reflexive teachers in doing their role as teachers, identify the students' learning style, and identify the development of the teachers' development in teaching. Thus, the experiential learning purposefully proposed teachers to engage with their students in direct experience and have the reflection on learning in order to enhance knowledge, increase skills, and develop the values of the teaching and learning.

To bring the theory above in listening classroom activities, the class is guided by the experiential learning steps whereas the focus is the class story language experience. As the first step, learners explore some stories to be heard by them (experience and do). The teacher facilitates the exploration and guides them through the steps. Therefore, the steps should be prepared first by the teachers. On the other hand, the students are active participants. The second step, this step includes sharing and processing which allow students and the teacher to describe what happened during the listening activity. They also consciously reflect their experience during the story activity. This step becomes the beginning critiquing the activity. Next step, students are generally assigned to think to make/create their own interpretation of the story in the listening activity. Finally, the last step allows the students to experiment by themselves of how to tell their story in order to be heard by other classmates.

Moreover, by applying experiential learning focusing on the class story language experience, the students can get more enthusiastic in listening learning process. They can have an opportunity to participate actively in several situations such as before listening, while listening, and after the listening activity. Moreover, it can be argued that they can experience a real experience and real object in the listening activity. Finally, it can be an easy lesson to be remembered by the students. Herrell \& Jordan (2000, cited in Lestari \& Setyawan (2017)) stated that the real object or experience can help students learn the lesson(s) in the learning activity.

\section{Research Objective}

The objective of this research is to measure the effectiveness of the Experiential Learning Model through the implementation of the Class Story Using Language Experience for grade X1 in SMAN 1 Telaga Biru.

\section{Research Problem}

Do the students (EFL students) in grade X1 in SMAN 1 Telaga Biru have better achievement in listening comprehension after getting the implementation of the Experiential Learning Model focusing on the Class Story Using Language Experience?

\section{RESEARCH METHOD}

\section{Design and Participants}

This study is an experimental research. The research design used in this current study was pre-experimental research. The design of this study involved one class of the grade eleventh (XI) at SMAN 1 Telaga Biru. The class consisted of 
27 students who were the subjects of the research. In teaching listening comprehension, the researcher used experiential learning approach focusing on the implementation of the class story using language experience in class XI. Since this was a pre-experimental research, the researcher did not need any control groups/class (Latief, 2016). All the researcher needed to be was just an experimental group.

\section{Collecting and Analyzing the Data}

In collecting the data, the researcher used an interview, an observation, the test and the documentation. The interview was done by the researcher in order to have a need analysis with the English teacher and some of the students in grade XI. The researcher also did an observation of the learning process of the listening classroom activity. Then researcher, then, provide a pre-test in XI class to find out the students' listening comprehension. By doing these activities, it is found that the students had problems in listening comprehension. However, the teaching method should be varied and encouraged students to be more enthusiastic in listening learning process.

Therefore, the researcher implemented the alternative way in teaching listening. The implementation of the research was used the experiential learning focusing on the implementation on the class story using language experience. After the treatments, the researcher provided a post-test in terms of the result of the implementation of the treatments. In the last step of the research, the researcher analyzed the data based on the result of the post-test.

In calculating the data, the researcher calculated the mean and standard deviation.

\section{Mean}

The arithmetic average was calculated when grading classroom test. The formula is as follows:

$$
\begin{aligned}
& \bar{x}=\frac{\sum x}{n} \\
& X: \text { Mean } \\
& \sum \text { : Sum of score } \\
& \text { N: Number of the students. }
\end{aligned}
$$

\section{FINDING AND DISCUSSIONS}

\section{The Post-test Result}

The post-test was used as the result of the students' achievement in listening comprehension by using experiential learning approach focusing on the implementation of the class story using language experience. Providing this post-test was proposed to find out the students listening ability particularly on their listening comprehension. The post-test was conducted on July $25^{\text {th }}, 2017$. There were 27 students who took the post-test. Moreover, this post-test was conducted in the form of worksheet consisted of multiple choice questions and oral test.
Based on Table 1, it shows that the highest score was 94 and the lowest score was 65 . Moreover, the mean of the overall the data above was 80,6 . In conclusion, the result showed that the effectiveness of the implementation of the treatment in the pre-experimental research. It also can be explained that the score of the mean was higher than the criteria of the minimum completeness (KKM). Further, the KKM was 75. The data also indicated that there were $74 \%$ of 27 students or 20 students who passed the criteria minimum completeness (KKM).

\section{The Effectiveness of Teaching Listening Comprehension Using Experiential Learning (The Class Story Using Language Experience)}

To implement the experiential learning in listening classroom activities focusing on the class story using language experience, the researcher as well as the teacher applied some steps as the teaching scenario. Those steps could be illustrated in the picture below Figure 2.

\section{Plan}

The teacher has planned the teaching scenario of the listening. The planning of the teaching was trying to determine the learning objectives and the kinds or characteristic of the students.

\section{Prepare}

After the first step has been completed, the teacher prepared the materials on listening, rubrics, and assessment tools. The teacher also ensured that everything was ready before the teaching listening activities began.

\section{Facilitate}

In the teaching and learning process, the teacher facilitated the students in learning something from listening activities.

Table 1. Post-test score of experimental class

\begin{tabular}{lccccc}
\hline No. & Students & Score & No. & Students & Score \\
\hline 1 & X1 & 70 & 15 & X15 & 82 \\
2 & X2 & 70 & 16 & X16 & 76 \\
3 & X3 & 85 & 17 & X17 & 90 \\
4 & X4 & 68 & 18 & X18 & 88 \\
5 & X5 & 82 & 19 & X19 & 86 \\
6 & X6 & 90 & 20 & X20 & 94 \\
7 & X7 & 76 & 21 & X21 & 82 \\
8 & X8 & 87 & 22 & X22 & 86 \\
9 & X9 & 90 & 23 & X23 & 74 \\
10 & X10 & 85 & 24 & X24 & 90 \\
11 & X11 & 75 & 25 & X25 & 68 \\
12 & X12 & 78 & 26 & X26 & 72 \\
13 & X13 & 65 & 27 & X27 & 76 \\
14 & X14 & 90 & & & \\
\hline
\end{tabular}




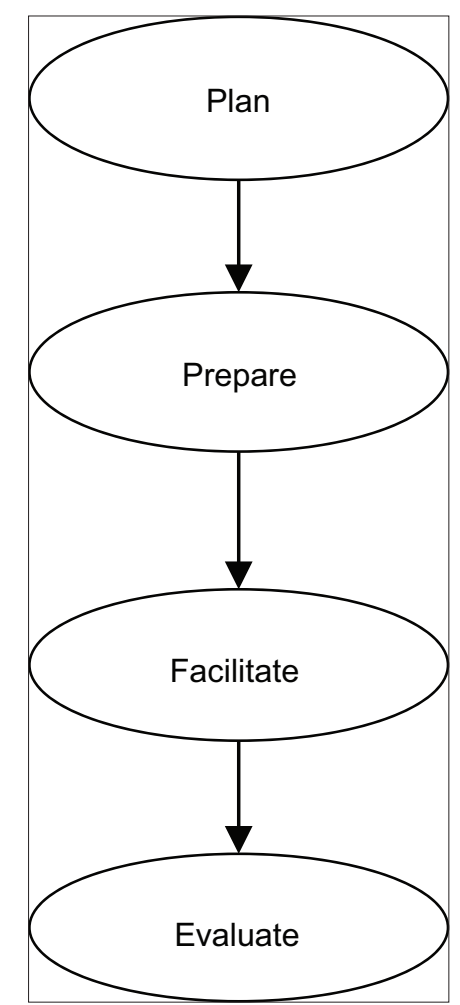

Figure 2. Steps of teaching scenario

The teacher also gave some instructions or comments about what the students had to do in the current activities.

\section{Evaluate}

In short, the successfulness of the experiential learning in listening classroom focusing on the class story using language experience could be determined during the discussion sessions and reflections of the learning process. Moreover, the teacher has been prepared the assessment of the students' achievement after the implementation of the experiential learning in listening classroom activities.

Moreover, to find out the effectiveness of the teaching listening comprehension by using experiential learning focusing on the class story using language experience, the pretest, and the post-test were analyzed by the researcher as the comparison of the students' achievement in listening learning process before and after implementing the treatment. In implementing the treatment of the research, the teaching listening activity was guided by the experiential steps. As the first step, the teacher as the researcher prepared the lesson of listening. The topic of the lesson was about telling some stories. The teacher provided several stories to the students. These stories were about telling someone's experience. Before beginning the class, the teacher played those stories. Students had carefully to the speaker(s) because they would have the same opportunity in telling the same story.

The class has been divided by the teacher into a small group. Every group did not consist of more than 3 students (student 1, student 2, and student 3 ). The class finally had 9 small groups. In this step, each group had a story given by the teacher. One of the member groups took a part to be a reader who wanted to read the given story loudly while the other students listened to the story read by their friend (experiencing and doing). After having this activity, the next activity was that the students sat in a big group. There were 3 big groups in this listening activity. The entire student sat in based on the number they got, for example, the student number 1 should sit with the other students who got number 1 . It was also the same with the other number (students 2 and 3). All the students would have the same opportunity to talk something and the other friend had to listen to their friend (sharing and observing). The purpose of this activity was to gain the students attention of what information they got from their friends. Therefore, in the next step, every group would have a discussion session in their own group (thinking). The students were actually expected to think critically about this step because they had to discuss the topic they have heard from their friends. Moreover, they may also write down several words/sentences they make them confused when they listen to their friends and can be discussed directly in their group in terms of the friends' confirmation. After doing this activity, all students went back to their first seat which was not in the group. As the last step, each student prepared the topic they were going to tell in the class. The topic could be related to the listening audio that they have heard from the native speaker and their friends' voice.

As the additional activity, the teacher provided a task at the end of the class. The task was still about the stories they have discussed. The types of the questions were multiple choice questions regarding the audio played. After collecting their works, their score from this.

\section{Pre-test and Post-test of the Grade X1}

Both pre-test and post-test were conducted by the researcher in the class X1 as the experiment class. After having the scores of the pre-test from all respondents, the lesson plans were designed based on the experiential learning. The learning process in listening activities has been done before having the post-test. The post-test finally was conducted after doing all the activities in order to have the result of the treatment in the listening classroom using experiential learning focusing on the class story using language experience.

\section{CONCLUSIONS}

Based on the findings of this study, it can be concluded that the researcher found the students' achievement in listening comprehension by using experiential learning focusing on the class story language experience. It was found that the students' scores were achieved after getting the treatment in listening comprehension based on the result of their post-test compared to their pre-test. In relation to the result of the pretest, it showed that the mean of the pre-test was 60 . In contrast, the mean of the post-test was 80,6 . It can be explained that the scores met the criteria of minimum completeness (KKM) 75.

By analyzing this result, it can be indicated that this result answers the objective and the problem of the research. The pre-experimental research by implementing the Experiential Learning Model in EFL listening classroom can be used 
as the learning model in the listening classroom. It can be seen from the students' achievement after implementing this learning model. Most of the students have better achievement in their listening comprehension. This achievement can be compared with both their pre-test (before implementing the treatment) and post-test (after getting the treatment).

By considering the overall result of this study, the researcher would like to give some recommendations and suggestions which might be useful for the teachers/lecturers and other relevant researchers. For teachers, they may consider the use of the approach, method, or technique in teaching listening. As the consideration, teaching listening using experiential learning could be an appropriate way to teach listening comprehension. The students will not get bored in the classroom because they involve themselves in teaching and learning process terms of interacting with other classmates/ friends. It is because listening is not just about teaching test-listening. But it is about how they can understand and be comprehended in their listening ability. Moreover, by having the result of this research, the current researcher was hoping to the future researcher(s) who want to conduct a similar study that they may have the findings of this research as the reference of their research. Thus, it is really expected that there will be another more effective way to teach listening in order the improvement of the teaching listening to the EFL learners.

\section{REFERENCES}

Ahmadi, S.M. (2016). The Importance of Listening Comprehension in Language Learning. International Journal of Research in English Education, 1(1), 7-10.

Albadawi, K.H., (2016). Enhancing EFL Learners' Listening Skill through Intensive Listening Activities. International Journal of English Language, Literature an Humanities, 4(12), 26-40.

Azmi, B. M., Celik, B., Yidliz, N., \& Tugrul, M. C. (2014). Listening Comprehension Difficulties Encountered by Students in Second language Learning Class. Journal of Educational and Instructional Studies in the wwWorld, 4(4), 1-6.

Basthomi, Y. (2012). Penelitian Naratif dalam Linguistik Terapan. Malang: Penerbit Bintang Sejahtera.

Brown, H.D. (2015). Teaching by Principles An Interactive Approach to Language Pedagogy. (4th Ed.). Pearson Education, 10 Bank Street, White Plains, NY 10606.

Cohen, L. Manion, L. \& Morrison, K. (2007). Research Methods in Education. USA \& Canada: Routledge.

Cresweell, J.W. (2012) Educational Research, University of Nebraska-Lincoln: PEARSON.
Debero, A. (2014) Action Research on the Implementation of Peer Assessment in Teaching Writing: The Case of Ansho Secondary and Preparatory School, SNNPRS. Haramaya University.

Farvardin, M.T. (2017). Probing the Relationship between Vocabulary Knowledge and Listening Comprehension of Iranian Lower-Intermediate EFL Learners. International Journal of Applied Linguistics \& English Literature, 6(5). 273-278.

Flowerdew, J., \& Miller, L. (2005). Second language listening: theory and practice. New York: Cambridge University.

Press.Gilakjani, A.P. \& Sabouri, N.B. (2016). Learners' Listening Comprehension Difficulties in English Langauge Learning: A literature Review. Canadian Center of Science and Education, 9(6), 123-133.

Khuziakhmetov, A.N., \& Porchesku, G.V. (2016). Teaching Listening Comprehension: Bottom-Up Approach. International Journal of Environmental \& Science Education. 11(8), 1889-2001. DOI: 10.12973/ ijese.2016.572a.

Kolb, D.A. (1984). Experiential Learning: Experience as the source of learning and development. Englewood Cliffs, N.J.: Prentice-Hal.

Kolb, D.A. (2015). Experiential Learning: Experience as the Source of Learning and Development. United State of America.

Kurita, T. (2012). Issues in Second Language Listening Comprehension and the Pedagogical Implications. Accents Asia, 5(1), 30-44.

Latief, M.A. (2016). Research Methods on Language Learning. An Introduction. Malang: Universitas Negeri Malang, Penerbit dan Percetakan.

Lightbown, P. M., \& Spada, N. (2006). How languages are learned (3rd ed.). Oxford: Oxford University Press.

Saville-Troike, M. (2005). Introduction Second Language Acquisition. UK: The Edinburgh Building.

Sharlanova, V. (2004). Experiential Learning. Trakia Journal of Science. 2 (4). 36-39.

Stæhr, L. S. (2009). Vocabulary knowledge and advanced listening comprehension in English as a foreign language. Studies in Second Language Acquisition, 3(1), 577-607.

Tahir, I. (2017). ENGLISH PEDAGOGY THROUGH HOLISTIC APPROACH FOR EFL STUDENTS'ENGAGEMENT IN INDONESIA. PEOPLE: International Journal of Social Sciences, 3(1), 273-287.

Ulum, O.G. (2015). Listening: The Ignored Skill in EFL Context. International Journal of Humanities Social Sciences and Education, 2(5), 257-270. 